\title{
Degrees of Kidney Disease in Nigerian Adults with Sickle-Cell Disease
}

\author{
John C. Aneke ${ }^{a, c}$ Adegbola O. Adegoke ${ }^{d}$ Anthony A. Oyekunle ${ }^{c}$ \\ Patrick O. Osho ${ }^{c}$ Abubakra A. Sanusi ${ }^{\mathrm{e}}$ Emmanuel C. Okocha ${ }^{\mathrm{a}}$ Nancy C. Ibeh $^{\mathrm{b}}$ \\ Norah O. Akinolac Muheez A. Durosinmic \\ a Department of Haematology, Nnamdi Azikiwe University Teaching Hospital, and ${ }^{\mathrm{b}}$ Department of Medical \\ Laboratory Science, Nnamdi Azikiwe University, Nnewi, and Departments of ${ }^{\mathrm{C}}$ Haematology, ${ }^{\mathrm{d}}$ Chemical Pathology \\ and ${ }^{\mathrm{e}}$ Medicine, Obafemi Awolowo University Teaching Hospital, Ile-Ife, Nigeria
}

\section{Key Words}

Chronic kidney disease $\cdot$ Creatinine clearance $\cdot$ Sickle-cell disease

\begin{abstract}
Objective: To study degrees of chronic kidney disease (CKD) using creatinine clearance in adult Nigerian patients with sickle-cell disease (SCD). Methods: One hundred SCD patients, made up of 79 HbSS (homozygous haemoglobin S) patients and $21 \mathrm{HbSC}$ (heterozygous haemoglobins S and C) patients, were investigated prospectively, along with 50 normal controls. Their sociodemographic data, weight and drug history were documented. Each participant underwent dipstick urinalysis, and creatinine clearance was calculated following a 24-hour urine collection and serum creatinine measurement. They were categorized into stages of CKD based on the creatinine clearance. Results: Of the $79 \mathrm{HbSS}$ patients, $14(18 \%), 28(35 \%), 33(42 \%)$ and $4(5 \%)$ had stage 1, 2, 3 and 4 CKD, respectively. In the HbSC group, 3 (14\%), 9 (43\%) and 9 (43\%) patients had stage 1, 2 and 3 CKD, respectively. Proteinuria was noted in 16 (20\%) HbSS patients but not in any of the HbSC patients. Of the subjects aged $\leq 24$ years $(n=49)$, $9(18 \%), 18(37 \%), 21(43 \%)$ and $1(2 \%)$ had stage 1, 2, 3 and 4 CKD, respectively. Of those aged $>24$ years $(n=51), 8(16 \%)$,
\end{abstract}

\section{KARGER}

E-Mail karger@karger.com www.karger.com/mpp
(C) 2014 S. Karger AG, Basel

1011-7571/14/0233-0271\$39.50/0

This is an Open Access article licensed under the terms of the Creative Commons Attribution-NonCommercial 3.0 Unported license (CC BY-NC) (www.karger.com/OA-license), applicable to the online version of the article only. Distribution permitted for non-commercial purposes only.
19 (37\%), 21 (41\%) and 3 (6\%) had stage 1, 2, 3 and 4 CKD, respectively. None of the subjects had stage 5 CKD. Conclusion: In this study, the adult subjects with SCD had various degrees of CKD. Adequate follow-up and active intervention are advocated to delay the onset of end-stage nephropathy.

ㄷ) 2014 S. Karger AG, Basel

\section{Introduction}

Sickle-cell disease (SCD) is a heterogeneous disorder affecting multiple organ systems in the body $[1,2]$. Indeed, end-organ dysfunction has a huge impact on survival, especially in young adults [3]. Recurrent vaso-occlusion [4], coupled with the haemodynamic changes of chronic anaemia lead to functional and structural changes in the kidneys. These morphological, laboratory and clinical changes arising from the effects of SCD on the kidneys constitute what has been described as sickle-cell nephropathy (SCN). They range from haematuria, varying degrees of proteinuria and renal failure syndromes to glomerular and tubular abnormalities $[5,6]$ which may ultimately progress to chronic kidney disease (CKD) [7, 8]. End-stage kidney disease has been identified as the most severe presentation of SCN, with a huge impact on 
morbidity and mortality, making early identification and management important [9].

Measurement of the glomerular filtration rate (GFR) using endogenous markers such as serum creatinine (creatinine clearance) offers a good measure of renal function in both health and disease [10]. The burden of SCN has been carefully studied in the works by Aleem [11] and Arogundade et al. [12], where up to $22.5 \%$ of SCD patients studied in Saudi Arabia and Nigeria, respectively, had subnormal creatinine clearance. Creatinine clearance may thus provide a means to determine the severity of renal pathology and its progression, and therefore provides insight into the natural history of SCN. The objective of this study was to evaluate, using creatinine clearance, the severity of renal disease in adult Nigerians with SCD.

\section{Subjects and Methods}

This prospective study took place over a period of 7 months. Ethical approval was obtained from the Institutional Ethics Review Committee of the Obafemi Awolowo University Teaching Hospital, Ile-Ife, Nigeria, and all subjects and controls gave their informed consent. Subjects included patients with confirmed SCD who attended the outpatient clinic at the Department of Haematology, Obafemi Awolowo University Teaching Hospital, Ile-Ife. They were studied in the steady state, i.e. with no acute illness or crisis for at least 2 weeks prior to recruitment. Controls were agematched, healthy undergraduates from the Obafemi Awolowo University, Ile-Ife, with the haemoglobin AA phenotype. Relevant clinical information was recorded for each participant, including age, gender, weight and a brief drug history. Exclusion criteria were oedema, ketosis and current treatment with drugs such as cotrimoxazole, probenecid or cephalosporin, known to reduce creatinine tubular secretion and to interfere with the alkaline picrate assay (Jaffé's reaction) for the serum creatinine assay [13].

A 24-hour urine collection was done for all subjects and controls, at the end of which blood and urine samples were collected for serum creatinine measurement and urinalysis. Urinalysis was done using Combi-9 dipsticks (Medi-test Combi-9, Macherey-Nagel, GmbH \& Co., Düren, Germany). Both urinary and serum creatinine measurements were taken using Jaffé's method [14]. The staging of kidney disease was based on the Kidney Disease Outcome Quality Initiative (K/DOQI) recommended classification system [15] as follows: stage $1 \mathrm{GFR}>90 \mathrm{ml} / \mathrm{min} / 1.73 \mathrm{~m}^{2}$, stage 2 GFR $60-89 \mathrm{ml} / \mathrm{min} / 1.73 \mathrm{~m}^{2}$, stage 3 GFR $30-59 \mathrm{ml} / \mathrm{min} / 1.73 \mathrm{~m}^{2}$, stage 4 GFR $15-29 \mathrm{ml} / \mathrm{min} / 1.73 \mathrm{~m}^{2}$ and stage 5 GFR $<15 \mathrm{ml} /$ $\mathrm{min} / 1.73 \mathrm{~m}^{2}$.

\section{Statistical Analysis}

The Statistical Package for Social Sciences version 17 and Microsoft Excel 2007 computer software were used for all data collection and analysis. $\mathrm{p}<0.05$ was considered significant.
Table 1. Characteristics of all HbSS and HbSC subjects

\begin{tabular}{llrrrlll}
\hline & Total & Stage 1 & Stage 2 & Stage 3 & Stage 4 Stage 5 \\
\hline HbSS patients & $79(100)$ & $14(18)$ & $28(35)$ & $33(42)$ & $4(5)$ & $0(0)$ \\
$\quad$ Proteinuria & $16(20)$ & $2(13)$ & $3(19)$ & $7(44)$ & $4(25)$ & $0(0)$ \\
$\quad$ No proteinuria & $63(80)$ & $12(19)$ & $25(40)$ & $26(41)$ & $0(0)$ & $0(0)$ \\
HbSC patients & $21(100)$ & $3(14)$ & $9(43)$ & $9(43)$ & $0(0)$ & $0(0)$ \\
Age & & & & & & \\
$\quad<24$ years & $49(100)$ & $9(18)$ & $18(37)$ & $21(43)$ & $1(2)$ & $0(0)$ \\
$\quad>24$ years & $51(100)$ & $8(16)$ & $19(37)$ & $21(41)$ & $3(6)$ & $0(0)$
\end{tabular}

Figures denote the number of patients, with the percentage in parentheses.

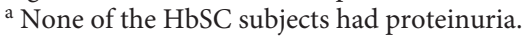

\section{Results}

The haemoglobin phenotypes of the subjects were HbSS (homozygous haemoglobin S) where HbS (sickle haemoglobin) is inherited from both parents $(\mathrm{n}=79)$ and HbSC (heterozygous haemoglobins S and C) where HbS is inherited from one parent and $\mathrm{HbC}$ is inherited from the other parent $(n=21)$. There were 40 male and $60 \mathrm{fe}$ male subjects. The controls $(n=50)$ consisted of 29 males and 21 females. The HbSS subjects were significantly younger than the HbSC subjects (mean age $25.4 \pm 6.8$ vs. $29.3 \pm 9.0$ years; $p=0.03$ ). The mean creatinine clearance of the HbSS versus the HbSC subjects showed no significant difference $(66.3 \pm 27.5$ vs. $68.8 \pm 22.0 \mathrm{ml} / \mathrm{min} ; \mathrm{p}=$ 0.70).

Among the 79 patients with HbSS, 14 (18\%), 28 (35\%), $33(42 \%)$ and $4(5 \%)$ had stage $1,2,3$ and 4 CKD, respectively; none had stage $5 \mathrm{CKD}$ (table 1). Proteinuria was present in $16(20 \%)$ of the HbSS subjects. In the HbSC group, 3 patients (14\%) had stage 1 , and $9(43 \%)$ had stage 2 and 3 CKD each; none had stage 4 or 5 disease or proteinuria (table 1 ).

A more detailed analysis of all 49 subjects younger than 24 years showed that 9 (18\%), 18 (37\%), 21 (43\%) and $1(2 \%)$ had stage $1,2,3$ and 4 CKD, respectively, while the corresponding data for the 51 subjects older than 24 years were 8 (16\%), 19 (37\%), $21(41 \%)$ and $3(6 \%)$, respectively (table 1).

\section{Discussion}

In this study, $47 \%$ of the HbSS subjects and $43 \%$ of the $\mathrm{HbSC}$ subjects who had a GFR $<60 \mathrm{ml} / \mathrm{min} / 1.73 \mathrm{~m}^{2}$ (although there was no follow-up for 3 months) highlighted 
the magnitude of CKD in patients with SCD. The relatively high prevalence of renal failure in this cohort could be due to the proximal tubular activity, both secretory and reabsorptive, that has been reported to be supranormal in SCD $[5,7,16]$ and includes increased tubular transport of creatinine and, consequently, an increased creatinine clearance $[16,17]$.

The GFR of $60-89 \mathrm{ml} / \mathrm{min} / 1.73 \mathrm{~m}^{2}$ in $35 \%$ of the HbSS patients and $43 \%$ of the HbSC patients could lead to a loss of renal function and cardiovascular complications as indicated in previous studies $[18,19]$. The British guideline on the classification of CKD recognizes this subgroup as having a tendency for worsening kidney function and cardiovascular disease [20]. Similarly, the K/DOQI also recognizes that such individuals are at risk of a progressive decline in kidney function [15].

SCN and indeed other forms of kidney disease usually begin with proteinuria [6], and as such, this is an important marker of renal pathology. Twenty percent of the HbSS cohort had proteinuria, which is similar to the $22.3 \%$ reported by Iwalokun et al. [21] and the $28 \%$ reported by Abdu et al. [22]. To the contrary, Bolarinwa et al. [23] reported a higher prevalence of proteinuria (50\%) in their HbSS cohort; a probable explanation for this high level of proteinuria could be the inclusion of individuals with both microalbuminuria and macroalbuminuria in their study. Proteinuria was seen in all stages of CKD in our HbSS study subjects; the majority of those with proteinuria had stage $3 \mathrm{CKD}$. Stage 3 has been reported to represent a critical point in the spectrum of $\mathrm{CKD}$, as it marks the beginning of established kidney disease according to the K/DOQI classification [15]. An earlier report by Abdu et al. [22] from Kano, north central Nigeria, noted that as much as $50 \%$ of SCD patients with proteinuria had CKD. This finding further underscores the importance of proteinuria in the assessment of renal status in SCD.
Previous reports on Nigerian SCD patients identified age as a significant predictor of kidney disease and as correlating with GFR [12]. Indeed, end-organ damage in this group of patients becomes more pronounced with advancing age [24]. Our study population consisted of young adults with a mean age of $26.22 \pm 7.42$ years. There was, however, no significant difference in the relative frequency of the various stages of CKD when the subjects were subclassified according to age, even though SCD subjects older than 24 years did appear to have more advanced stages of CKD than those younger than 24 years (6 vs. $2 \%$, respectively).

Our study has highlighted the magnitude of significant kidney disease amongst SCD patients in our population who are predominantly from the southwest region of $\mathrm{Ni}$ geria. Indeed, earlier reports from the same region of the country $[25,26]$ identified SCD as a significant contributor to the incidence of chronic renal failure and childhood nephrotic syndrome.

The major limitation of this study was the lack of follow-up of the subjects for a period of 3 months, which would have enabled a more precise definition of CKD.

\section{Conclusion}

In this study, the SCD population had various stages of CKD, mostly stages 2 and 3, based on the K/DOQI classification system. We advocate using this system for our patients, with a view to detecting CKD in its early stages, in order to delay the onset of end-stage kidney disease. This is made even more necessary by the relatively poor outcomes associated with renal replacement therapy in SCD patients, particularly in settings with limited resources.

\section{References}

$>1$ Kutlar A: Sickle cell disease: a multigenic perspective of a single-gene disorder. Med Princ Pract 2005;14(suppl 1):15-19.

$\checkmark 2$ Adekile AD: What's new in the pathophysiology of sickle cell disease? Med Princ Pract 2013;22:311-312.

$>3$ Platt OS, Brambilla DJ, Ross WF, et al: Sickle cell disease: Life expectancy and risk factors for early death. N Engl J Med 1994;330:1639_ 1664.
4 Akar NA, Adekile A: Ten-year review of hospital admissions among children with sickle cell disease in Kuwait. Med Princ Pract 2008; 17:404-408.

$\checkmark 5$ Phuong-Thu TP, Phuong-Chi TP, Alan HW, et al: Renal abnormalities in sickle cell disease. Kidney Int 2000;57:1-8.

6 Walker BR, Alexander F, Birdsall TR, et al: Glomerular lesions in sickle cell nephropathy. JAMA 1971;215:437-440.

$>7$ Ataga KI, Orringer EP: Renal abnormalities in sickle cell disease. Am J Hematol 2000;63: 205-211.
8 Scheinman JI: Sickle cell disease and the kidney. Semin Nephrol 2003;23:66-76.

9 Okafor UH, Aneke E: Outcome and challenges of kidney transplant in patients with sickle cell disease. J Transplant 2013;2013:614610.

10 Smith HW: Comparative physiology of the kidney; in Smith HW (ed): The Kidney: Structure and Function in Health and Disease. New York, Oxford University Press, 1951, pp 520574. 
11 Aleem A: Renal abnormalities in patients with sickle cell disease: a single-centre report from Saudi Arabia. Saudi J Kidney Dis Transpl 2008;19:194-199.

$>12$ Arogundade FA, Sanusi AA, Hassan MO, et al: An appraisal of kidney dysfunction and its risk factors in patients with sickle cell disease. Nephron Clin Pract 2011;118:c225-c231.

13 Lascano ME, Poggio ED: Kidney function assessment by creatinine-based estimation equations; in Carey WD (ed): Disease Management Project: Nephrology. Cleveland, Center for Continuing Education, 2010, p 1.

14 Burtis CA, Ashwood ER: Tietz Fundamentals of Clinical Chemistry. Philadelphia, W.B. Saunders Co., 2001, pp 419-421.

15 K/DOQI: Clinical practice guidelines for chronic kidney disease: evaluation, classification, and stratification. Am J Kidney Dis 2002; 39:S1-S266.

16 Allon M: Renal abnormalities in sickle cell disease. Arch Intern Med 1990;150:501-504.
17 De Jong P, de Jong-Van Den Berg T, Sewrajsingh $\mathrm{G}$, et al: The influence of indomethacin on renal haemodynamics in sickle cell anaemia. Clin Sci 1980;59:245-250.

18 Chauhan V, Vaid M: Dyslipidemia in chronic kidney disease: managing a high risk combination. Postgrad Med 2009;121:54-61.

19 Sarnak MJ, Levey AS: Cardiovascular disease and chronic renal disease: a new paradigm. Am J Kidney Dis 2002;34:117-131.

20 Clinical guideline 73: Chronic Kidney Disease. London, National Institute for Health and Clinical Excellence, 2008, pp 4.

21 Iwalokun BA, Iwalokun SO, Hodonu SO, et al: Evaluation of microalbuminuria in relation to asymptomatic bacteruria in Nigerian patients with sickle cell anemia. Saudi J Kidney Dis Transpl 2012;23:1320-1330.

22 Abdu A, Emokpae MA, Uadia PO, et al: Proteinuria among adult sickle cell anemia patients in Nigeria. Ann Afr Med 2011;10:3437.
23 Bolarinwa RA, Akinlade KS, Kuti M, et al: Renal disease in adult Nigerians with sickle cell anemia: a report of prevalence, clinical features and risk factors. Saudi J Kidney Dis Transpl 2012;23:171-175.

24 Morgan AG, Shah DJ, William W: Renal pathology in adults over 40 with sickle cell disease. West Indian Med J 1987;36:241-250.

25 Odubanjo MO, Okolo CA, Oluwasola AO, et al: End-stage renal disease in Nigeria: an overview of the epidemiology and the pathogenetic mechanisms. Saudi J Kidney Dis Transpl 2011;22:1064-1071.

26 Olowu WA, Adelusola KA, Adefehinti O, et al: Quartan malaria-associated childhood nephrotic syndrome: now a rare clinical entity in malaria endemic Nigeria. Nephrol Dial Transplant 2010;25:794-801. 